Bağcı, H. ve Ünal, Y. (2013). İlköğretim 8. sınıf Türkçe ders kitaplarındaki metinlerin okunabilirlik düzeyi. Ana Dili Eğitimi Dergisi, 1(3), 12-28.

Ana Dili Eğitimi Dergisi
Journal of Mother Tongue
Education
ADED - JOMTE
www.anadiliegitimi.com

\title{
İlköğretim 8. Sınıf Türkçe Ders Kitaplarındaki Metinlerin Okunabilirlik Düzeyi
}

\author{
Hasan Bağcl ${ }^{*}$ \\ Yasemin Ünal ${ }^{* *}$
}

\begin{abstract}
Özet
Bu çalışmada ilköğretim sekizinci sınıf Türkçe ders kitaplarında yer alan metinlerin okunabilirlik düzeyleri incelenmiştir. Çalışmanın amacı, son zamanlarda çok yaygınlaşan okunabilirlik kavramının Türkçe öğretimi için kullanılan kitaplarda ne kadar uygulandığını ortaya çıkarmaktır. Çalışmada Türkçe ders kitaplarında yer alan metinlerin öğrencilerin okuma- anlama seviyelerine ne kadar uygun olduğunu belirlemek amaçlanmıştır. Metinlerin okunabilirliklerini belirlemek amaçlı Türkçe metinler için uyarlanmış olan iki okunabilirlik formülü kullanılmıştır. Çalışmada Türkiye'nin değişik illerinde okutulan iki adet 8. sınıf Türkçe ders kitabında yer alan bilgilendirici ve öyküleyici metinler incelenmiş şiirler çalışma kapsamına alınmamıştır. Yapılan çalışmanın sonucuna göre öyküleyici metinlerin okunabilirlik düzeylerinin öğrencilerin seviyelerine daha uygun olduğu görülmüştür.
\end{abstract}

Anahtar Kelimeler: okunabilirlik, metin, 8. sınıf Türkçe ders kitabı

\section{Readability of Texts in 8th Grade Turkish Textbooks}

\begin{abstract}
In this study, the primary education eighth grade located in Turkish textbooks text readability levels are explored. The purpose of the study; recently, the concept of readability used for teaching Turkish books spreading too much revealing that. The study of the texts contained in Turkish textbooks students reading comprehension levels intended to determine how much is appropriate. For purposes of determining their readability of texts adapted to Turkish texts used two readability formula. Two different provinces of Turkey in the study taught in $8^{\text {th }}$ grade Turkish textbooks, not informative and storytelling texts examined poems study. According to the results of the work done on a more appropriate level of readability levels of students in storytelling.

Keywords: readability, text, $8^{\text {th }}$ grade Turkish textbook
\end{abstract}

\section{Giriş}

Ülkemizde öğretim ortamlarında ders kitaplarının kullanılması oldukça yaygındır. Özellikle Türkçe dersinde öğretmenler dersi etkin kılmak amacıyla öncelikle ders kitaplarına başvurmaktadır. 2005 yılında yenilenmiş olan Türkçe Dersi Öğretim programında derste kullanılabilecek çok sayıda araç-gereç yer alırken aynı zamanda "Türkçe öğretiminde en belli başlı ve yaygın araç olarak

\footnotetext{
* Yrd. Doç. Dr., Mehmet Akif Ersoy Üniversitesi, Eğitim Fakültesi, Türkçe Eğitimi Bölümü. Burdur. E-posta: hbagci26@hotmail.com

${ }^{* *}$ Mehmet Akif Ersoy Üniversitesi, Eğitim Fakültesi, Türkçe Eğitimi Bölümü. Burdur. E-posta:

unalysmn@gmail.com
} 
geleneksel ders kitabını tanıyoruz" ifadesi de bulunmaktadır. Özbay (2002: 37) yapmış olduğu araştırmada Türkçe öğretmenlerinin derslerini büyük oranda $(\% 94,44)$ ders kitabına bağlı kalarak işlediklerini ortaya koymuştur. Ders kitaplarının bu öneminden dolayı öğrencilerin ve öğretmenlerin ihtiyaçlarını ve beklentilerini karşılayacak nitelikte hazırlanması gerekmektedir.

Sever'e (2003: 17) göre, temel okuma-yazma becerisinin kazanılmaya başlandığı ilköğretim dönemindeki çocukların öğretimde karşılaştıkları metinler ve kitaplar, onların öğrenimlerinin ileriki aşamalarında okuma alışkanlığı edinmiş birer okur olarak yetişmelerinde önemli bir sorumluluk üstlenir. Bu yüzden Türkçe derslerinde kullanılan materyallerin en başında yer alan ders kitaplarında bulunan metinler öğrencilerin düzeyine uygun olarak hazırlanmalıdır. Öğrencilerin dil gelişimi ve okuduğunu anlama düzeylerine uygun metinlerin hazırlanması öğrencilerin okuduğu metinleri amaçlandığı gibi anlamalarını sağlayacaktır. Bir metnin okunduğu zaman anlaşılması, o metnin okunabilirliğini göstermektedir. Bundan dolayı okunabilirlik okumada önemli bir yere sahiptir.

Okunabilirlik, çoğunlukla metinlerin nicel özellikleri yani cümle ve kelime uzunlukları ve bilinmeyen kelime sayısı göz önüne alınarak metnin güçlüğünü belirlemeyi amaçlar (Zorbaz, 2007: 89). Göğüş (1978) okunabilirliği, bir yazıyı belli bir düzeydeki öğrencinin okuyup anlayabilmesi şeklinde ifade etmiştir. Ateşman'a (1997: 71) göre ise okunabilirlik, okuyan tarafından metinlerin kolay ya da güç anlaşılır olma durumudur. Okunabilirlik formülleri, metnin yapısal özelliklerinden yola çıkarak metinleri okuma zorluklarına veya kolaylıklarına göre tanımlamayı ve sınıflandırmayı amaçlayan kestirim araçlarıdır (Çetinkaya, 2010:40). Okunabilirlik formülleri sayesinde öğrencilere düzeylerine uygun metinler seçilerek öğrencilerin öğrenme düzeyleri en üst seviyeye çıkarılabilir.

Okunabilirlik çalışmaları Türkiye'de 1990 'ı yıllarda başlamıştır. Illk olarak Türkçe metinlere uygun bir okunabilirlik formülü bulunmuyordu. İngilizce metinler için uyarlanmış okunabilirlik formülleri kullanılıyordu. Fakat bir dilin yapısı başka bir dile benzemediği için bu formüller Türkçe metinler için uygun değildi. 1990 'lı yıllarda Türkçe metinlerin okunabilirliği için iki çalışma yapılmıştır. Bu çalışmalardan ilki 1997 yılında Ateşman'ın hazırlamış olduğu okunabilirlik formülü, diğeri ise Çetinkaya'nın 2010 yılında hazırlamış olduğu okunabilirlik formülüdür.

Ateşman'ın okunabilirlik formülü iki değişken göz önüne alınarak oluşturulmuştur. Bu değişkenler; cümle uzunluğu ve kelime uzunluğudur. Ateşman'ın oluşturduğu formül ve bu formüle göre çıkan okunabilirlik sayısı ve bu sayı değeri aralığına denk gelen okuma düzeyleri şu şekildedir;

\footnotetext{
Okunabilirlik sayısı $=198.825-40.175$ x X1 $-2.610 \times$ X2

X1 = hece olarak ortalama kelime uzunluğu

X2 = kelime olarak ortalama cümle uzunluğu
} 
Tablo1: Ateşman Okunabilirlik Formülünde Türkçe Metinlerin Okunabilirlik Sayısına Göre Sınıflandırılması

\begin{tabular}{ll}
\hline & Okunabilirlik Sayısı \\
\hline Çok Kolay & $90-100$ \\
Kolay & $70-89$ \\
Orta Güçlükte & $50-69$ \\
Zor & $30-49$ \\
Çok Zor & $1-29$ \\
\hline
\end{tabular}

Çetinkaya 2010 yılında Türkçe metinlerin okunabilirliği ile ilgili bir formül oluşturmuştur. Bu formül ve formüle göre çıkabilecek okunabilirlik sayıları ve bu sayı değerleri aralığına denk gelen okuma düzeyleri şu şekildedir;

$$
\begin{aligned}
& \text { Çıkartma Puanı= 118.823- } 25.987 \times \text { OSU- 0.971x OTU } \\
& \text { OSU= Ortalama sözcük uzunluğu } \\
& \text { OTU= Ortalama tümce uzunluğu }
\end{aligned}
$$

Tablo2: Türkçe Metinlerinin Okunabilirlik Düzeylerinin Tanımlanması ve Sınıflandırılması

\begin{tabular}{lll}
\hline Okunabilirlik Puanı & Okunabilirlik Düzeyi & Eğitim Düzeyi \\
\hline $0-34$ & ENGELLi DÜZEY & 10.11. ve 12. Sınıf \\
$35-50$ & EĞiTSEL OKUMA & 8. ve 9. Sınıf \\
$51+$ & BAĞIMSIZ OKUMA & 5.6. ve 7. Sınıf \\
\hline
\end{tabular}

Okunabilirlik formülleri, metnin bireye veya sınıfa uygunluğu, anlaşılıp anlaşılmaması, iyi ya da kötü oluşu ile ilgili kesin sonuçlar vermemekte, yalnızca metnin yapısal okuma güçlük düzeyine yönelik bir fikir vermektedir; dolayısıyla okunabilirlik, ancak metnin nitel özellikleriyle birlikte ele alındığında kesin bir sonuca ulaştırabilir (Zorbaz, 2007). Yapılan çalışmalara göre okunabilirlik formülleri sadece metinlerin güçlügü hakkında fikir verebilir. Bu formüllerin yanı sıra metinlerin nicel özellikleri de dikkate alınarak ders kitaplarında yer alması gerekmektedir. Ders kitaplarında yer alan metinlerin öğrencilerin düzeylerine uygun olması eğitim ve öğretim ortamının istenen düzeye getirilebilmesi için son derece önem arz eden bir durumdur.

Bu sebeplerden dolayı bu çalışmada iki yayınevinin hazırlamış olduğu 8. sınıf Türkçe ders kitaplarında yer alan metinlerin okunabilirlik düzeyleri belirlenmiştir. Çalışmada yukarıda bahsedilen iki okunabilirlik formülü de kullanılmış ve bu formüllerden elde edilen sonuçlara göre metinler okunabilirlik düzeyine göre sınıflandırılmıştır.

\section{Yöntem}

\section{Problem Cümlesi}

Bu çalışmanın problem cümlesi “ 8. sınıf ders kitaplarında yer alan bilgilendirici ve öyküleyici metinlerin okunabilirlik düzeyleri nasıldır?" sorusudur. Bu sorunun cevabını bulmak için Türkçe 
metinler için oluşturulmuş iki okunabilirlik formülü uygulanmıştır. Bu probleme bağlı olarak alt problemler şunlardır:

a) 8. Sınıf Türkçe ders kitaplarındaki metinlerde ortalama sözcük ve tümce uzunluğu nedir?

b) 8. Sınıf Türkçe ders kitaplarındaki metinlerin okunabilirlik güçlüğü nedir?

c) 8. Sınıf Türkçe ders kitaplarındaki bilgilendirici metinlerin okunabilirlik güçlüğü nedir?

d) 8. Sınıf Türkçe ders kitaplarındaki öyküleyici metinlerin okunabilirlik güçlüğü nedir?

\section{Evren ve Örneklem}

Bu çalışmada Milli Eğitim Bakanlığı Talim ve Terbiye Kurulunun 2008 Ağustos ayı ve 2010 Ekim ayı tebliğler dergisinde önerilen iki farklı yayınevine ait Türkçe ders kitabı kullanılmıştır. Bu kitaplar 2012- 2013 eğitim-öğretim yılında değişik illerde okutulan Bisiklet Yayınları ve MEB Yayınları'nca hazırlanan 8. sınıf Türkçe ders kitaplarıdır.

\section{İncelenen Materyaller}

Bu çalışmada MEB Yayınları (8. sınıf) ve Bisiklet Yayınları (8.sınıf) Türkçe ders kitapları incelenmiştir.

Çalışma kapsamında değerlendirilen ders kitabındaki bilgilendirici ve öyküleyici metinler incelenmiş şiirler çalışmada yer almamıştır. Kitapta yer alan okuma metinleri çalışma kapsamına dahil edilirken dinleme metinleri incelemeye alınmamıştır. Sonuçta toplam iki ders kitabındaki 56 (elli altı) metin incelenmiştir.

\section{Araştırmanın Modeli}

Yapılan bu çalışmada "tarama/betimleme modeli " kullanılmıştır.

\section{Uygulama}

Yapılan çalışmalarda metinlerin okunabilirlik düzeylerini belirlemek için birçok okunabilirlik formülü kullanılmıştır. Bunların çoğu İngilizce metinler için uyarlanmış okunabilirlik formülleri olduğu için Türkçe metinlere uygulanması Türkçe ve İngilizcenin farklı yapıda olmasından dolayı doğru sonuçlar vermeyecektir. Bu sebeple çalışmada Türkçe metinler için oluşturulmuş Ateşman (1997) ve Çetinkaya-Uzun okunabilirlik formülleri kullanılııştır.

Çalışma için iki ders kitabında bulunan öyküleyici ve bilgilendirici metinlerin hece, kelime ve cümleleri sayılmış, Ateşman(1997) ve Çetinkaya-Uzun okunabilirlik formülleri her metin için uygulanmıştır. Böylelikle farklı iki formüle göre metinlerin okunabilirlik düzeyleri ortaya çıkmıştır. Bu uygulamanın basamakları şöyle gerçekleştirilmiştir:

\section{Sözcüklerin sayılması}

2. Cümlelerin sayılması

3. Hecelerin sayılması

\section{Ortalama tümce uzunluğunun bulunması}

Toplam sözcük sayısının tümce sayısına bölünmesiyle ortalama tümce uzunluğu bulunur. 
Toplam sözcük sayısı

$\mathrm{OTU}=$

Toplam tümce sayısı

\section{Ortalama sözcük uzunluğunun bulunması}

Toplam seslem sayısının toplam sözcük sayısına bölünmesiyle ortalama sözcük uzunluğu bulunur.

Toplam seslem sayısı

OSU $=$

Toplam sözcük sayısı

\section{Formüllerin hesaplanması}

Ateşman formülünün uygulanması;

$O P=198,825-(40,175 . O S U-2,610.0 T U)$

Çetinkaya-Uzun formülünün uygulanması;

$O P=118,823-25,987 \times O S U-0,971 \times$ OTU

$O P=$ Okunabilirlik Puanı

OTU = Ortalama tümce uzunluğu

OSU = Ortalama sözcük uzunluğu

\section{Bulgular}

Bu bölümde incelenen iki adet 8. sınıf Türkçe ders kitabında yer alan metinlerin okunabilirlik düzeylerine ilişkin tablolar verilmiştir. Tabloda yer alan kısaltmalar şu şekildedir;

OSU: Ortalama sözcük uzunluğu, OTU: ortalama tümce uzunluğu, OPU-1: Ateşman Okunabilirlik Puanı, OPU-2: Çetinkaya-Uzun Okunabilirlik Puanı'nı simgelemektedir. Metnin düzeyi kısmında metinlerin Ateşmen ve Çetinkaya-Uzun formüllerine göre okunabilirlik düzeyleri belirtilmektedir.

Tablo1: MEB Yayınları 8. Sınıf Türkçe Ders Kitabındaki Metinlerin Okunabilirlik Düzeyleri

\begin{tabular}{|c|c|c|c|c|c|c|c|}
\hline Metin Adı & $\begin{array}{l}\text { Metnin } \\
\text { Türü }\end{array}$ & $\begin{array}{l}\text { Metnin } \\
\text { Alt Türü }\end{array}$ & OSU & OTU & OPU-1 & OPU-2 & $\begin{array}{l}\text { Metnin } \\
\text { Düzeyi }\end{array}$ \\
\hline Kız Kalesi & Öyküleyici & Efsane & 2.526 & 11.16 & 68.216 & 42.344 & Orta-Eğitsel \\
\hline Eski Ankara Evleri & Bilgilendirici & $\begin{array}{l}\text { Gezi } \\
\text { yazısı }\end{array}$ & 2.745 & 12.363 & 56.278 & 35.485 & Orta-Eğitsel \\
\hline Robinson Crouse & Öyküleyici & Roman & 2.318 & 6.506 & 88.72 & 52.269 & $\begin{array}{l}\text { Kolay- } \\
\text { Bağımsız }\end{array}$ \\
\hline Atatürk'ten Anılar & Öyküleyici & Anı & 2.534 & 10.48 & 69.67 & 42.796 & Orta-Eğitsel \\
\hline Onuncu Yıl Nutku & Bilgilendirici & Nutuk & 2.960 & 11.058 & 51.046 & 31.165 & Orta-Engelli \\
\hline Atatürk ve Bilim & Bilgilendirici & Makale & 2.715 & 18.375 & 41.792 & 30.427 & Zor-Engelli \\
\hline $\begin{array}{l}\text { Atatürk'ün Millet } \\
\text { Sevgisi }\end{array}$ & Öyküleyici & Anı & 2.766 & 13.346 & 52.868 & 33.985 & Orta-Engelli \\
\hline Gazi & Öyküleyici & Anı & 2.376 & 10.724 & 75.381 & 46.665 & Kolay-Ĕgitsel \\
\hline
\end{tabular}


Tablo1(Devamı): MEB Yayınları 8. Sınıf Türkçe Ders Kitabındaki Metinlerin Okunabilirlik Düzeyleri

\begin{tabular}{|c|c|c|c|c|c|c|c|}
\hline İhtiyar Çilingir & Öyküleyici & Hikâye & 2.380 & 9.041 & 79.612 & 48.196 & Kolay-Eğitsel \\
\hline Gönül Mimarlarımız & Bilgilendirici & Biyografi & 3.054 & 12.087 & 44.582 & 27.723 & Zor-Engelli \\
\hline Nevruz ve Birlik & Bilgilendirici & Fikra & 3.102 & 12.535 & 41.487 & 26.041 & Zor-Engelli \\
\hline $\begin{array}{l}\text { Mehmet Akif ve } \\
\text { Safahat'ı Okumak }\end{array}$ & Öyküleyici & Hikâye & 3.212 & 9.178 & 45.829 & 26.442 & Zor-Engelli \\
\hline $\begin{array}{l}\text { Türklerde } \quad \text { Çiçek } \\
\text { Sevgisi }\end{array}$ & Bilgilendirici & Sohbet & 2.845 & 8.177 & 63.187 & 36.951 & Orta-Eğitsel \\
\hline Ergenekon Destanı & Öyküleyici & Destan & 2.515 & 7.24 & 78.889 & 46.436 & Kolay-Eğitsel \\
\hline Çiğdem Der ki & Öyküleyici & Hikâye & 2.526 & 7.949 & 76.597 & 45.462 & Kolay-Eğitsel \\
\hline Aşinasız & Bilgilendirici & Deneme & 2.756 & 9.00 & 64.613 & 38.471 & Orta-Eğitsel \\
\hline Ziyaret Günleri & Bilgilendirici & Sohbet & 2.934 & 7.073 & 62.492 & 35.711 & Orta-Eğitsel \\
\hline Türk Misafirperverliği & Bilgilendirici & Gezi Yazısı & 2.701 & 12.652 & 57.292 & 36.348 & Orta-Eğitsel \\
\hline $\begin{array}{l}\text { Basından Teknoloji } \\
\text { Haberleri }\end{array}$ & Bilgilendirici & $\begin{array}{l}\text { Haber } \\
\text { Yazısı }\end{array}$ & 3.151 & 17.571 & 26.374 & 19.877 & $\begin{array}{l}\text { Çok Zor- } \\
\text { Engelli }\end{array}$ \\
\hline $\begin{array}{l}\text { Anadolu'nun Bahtı } \\
\text { Açık Kara Treni }\end{array}$ & Öyküleyici & Hikâye & 2.709 & 8.671 & 67.36 & 40.006 & Orta-Eğitsel \\
\hline Bilgisayar Yalnızlığı & Bilgilendirici & Deneme & 2.985 & 12.121 & 47.268 & 29.483 & Zor-Engelli \\
\hline $\begin{array}{l}\text { Bir Varmış Bir } \\
\text { Yokmuş Televizyon } \\
\text { Bozulmuş }\end{array}$ & Öyküleyici & Hikâye & 2.441 & 8.189 & 79.385 & 47.438 & Kolay-Eğitsel \\
\hline $\begin{array}{l}\text { Petekten Peteğe } \\
\text { Telefon Görüşmesi }\end{array}$ & Bilgilendirici & $\begin{array}{l}\text { Haber } \\
\text { Yazısı }\end{array}$ & 3.002 & 11.838 & 47.323 & 29.317 & Zor-Engelli \\
\hline $\begin{array}{l}\text { Hayatta Başarının } \\
\text { Yolları }\end{array}$ & Bilgilendirici & Konferans & 2.630 & 13.256 & 58.567 & 37.607 & Orta-Eğitsel \\
\hline İki İyi İnsan & Öyküleyici & Hikâye & 2.461 & 10.393 & 72.83 & 44.778 & Kolay-Eğitsel \\
\hline Martı & Öyküleyici & Roman & 3.048 & 11.189 & 47.169 & 28.751 & Zor-Engelli \\
\hline Bir Başarı Öyküsü & Öyküleyici & Hikâye & 2.753 & 11.906 & 57.15 & 35.721 & Orta-Eğitsel \\
\hline $\begin{array}{l}\text { Bir Şey Olmak Çok } \\
\text { Şey Olmak }\end{array}$ & Bilgilendirici & Mektup & 2.682 & 8.583 & 68.675 & 40.792 & Orta-Eğitsel \\
\hline
\end{tabular}

Tablo(1) incelendiğinde on dört tane bilgilendirici metinden Ateşman Okunabilirlik Formülüne göre "Basından Teknoloji Haberleri" adlı metnin çok zor, "Atatürk ve Bilim", "Gönül Mimarlarımı"", "Nevruz ve Birlik", "Bilgisayar Yalnızlı̆ı̆" , "Petekten Peteğe Telefon Görüşmesi" adlı metinlerin zor, "Eski Ankara Evleri", "Onuncu Yıl Nutku", "Türklerde Çiçek Sevgisi", "Aşinasız", "Ziyaret Günleri", "Türk Misafir Perverliği", "Hayatta Başarının Yolları", " Bir Şey Olmak Çok Şey Olmak" adlı metinlerin orta düzeyde olduğunu görüyoruz. Çetinkaya-Uzun Okunabilirlik formülüne göre bu bilgilendirici metinlerden "Onuncu Yıl Nutku", "Atatürk ve Bilim", "Gönül Mimarlarımız", "Nevruz ve Birlik", "Basından Teknoloji Haberleri", "Bilgisayar Yalnızlığı", "Petekten Peteğe Telefon Görüşmesi" adlı metinlerin engelli, "Eski Ankara Evleri", "Türklerde Çiçek Sevgisi", "Aşinasız", "Ziyaret Günleri", "Türk Misafirperverliği", "Hayatta Başarının Yolları", "Bir Şey Olmak Çok Şey Olmak" adlı metinlerin eğitsel düzeyde olduğunu görmekteyiz. İki formüle göre kolay okuma düzeyinde metin bulunmazken her iki formüle göre "Eski Ankara Evleri", "Türklerde Çiçek Sevgisi", "Aşinasız", "Ziyaret Günleri", "Türk Misafirperverliği", "Hayatta Başarının Yolları" ve "Bir Şey Olmak Çok Şey Olmak" adlı metinler orta düzeyde, "Atatürk ve Bilim", "Gönül Mimarlarımız ", "Nevruz ve Birlik ", "Bilgisayar Yalnızlığı", 
"Petekten Peteğe Telefon Görüşmesi " adlı metinlerin zor ,"Basından Teknoloji Haberleri" adlı metnin çok zor düzeyde olduğunu görmekteyiz.

Tablo(1)'e göre on dört öyküleyici metinden Ateşman Okunabilirlik Formülüne göre "Mehmet Akif ve Safahat'ı Okumak", "Martı" adlı metinlerin zor, "Kız Kalesi", "Atatürk'ten Anılar", "Atatürk'ün Millet Sevgisi", "Anadolu'nun Bahtı Açık Kara Treni", "Bir Başarı Öyküsü" adlı metinlerin orta, "Robinson Crouse", "Gazi", "ihtiyar Çilingir", "Ergenekon Destanı", "Çiğdem Der Ki", " Bir Varmış Bir Yokmuş Televizyon Bozulmuş", "iki i̇yi İnsan" adlı metinlerin kolay; Çetinkaya-Uzun Okunabilirlik Formülüne göre bu metinlerden "Atatürk'ün Milet Sevgisi", "Mehmet Akif ve Safahat'ı Okumak", "Martı" adlı metinlerin engelli, "Kız Kalesi", "Atatürk'ten Anılar", "Gazi", "Ihtiyar Çilingir", "Ergenekon Destanı", "Çiğdem Der Ki", "Anadolu'nun Bahtı Açık Kara Treni", "Bir Varmış Bir Yokmuş Televizyon Bozulmuş", "iki İyi İnsan", "Bir Başarı Öyküsü" adlı metinlerin eğitsel, "Robinson Crouse" adlı metnin de bağımsız okuma düzeyinde olduğunu görmekteyiz. İki formüle göre, "Robinson Cruose" adlı metnin kolay, "Kız Kalesi", "Atatürk'ten Anılar", "Anadolu’nun Bahtı Açık Kara Treni", "Bir Başarı Öyküsü" adlı metinlerin orta, "Mehmet Akif ve Safahat'ı Okumak" ve "Martı" adlı metinlerin zor düzeyde olduğunu görmekteyiz.

Tablo(2): Bisiklet Yayınları 8. Sınıf Türkçe Ders Kitaplarındaki Metinlerin Okunabilirlik Düzeyleri

\begin{tabular}{|c|c|c|c|c|c|c|c|}
\hline Metin Adı & $\begin{array}{l}\text { Metnin } \\
\text { Türü }\end{array}$ & $\begin{array}{l}\text { Metnin } \\
\text { Alt Türü }\end{array}$ & OSU & OTU & OPU-1 & OPU-2 & $\begin{array}{l}\text { Metnin } \\
\text { Düzeyi }\end{array}$ \\
\hline $\begin{array}{ll}\text { Meraklı } & \text { Pandora } \\
\text { ve } & \text { Konuşan } \\
\text { Sandık } & \end{array}$ & Öyküleyici & Efsane & 2.555 & 6.455 & 79.331 & 50.16 & Kolay-Eğitse \\
\hline Aşk Mektupları & Öyküleyici & Hikâye & 2.579 & 8.863 & 72.082 & 43.198 & Kolay-Eğitse \\
\hline $\begin{array}{l}\text { Kazılık Dağının } \\
\text { Aslanı Boğaç Han }\end{array}$ & Öyküleyici & Destan & 2.476 & 7.756 & 79.109 & 46.949 & Kolay-Eğitse \\
\hline $\begin{array}{l}\text { Hayatın Hesaba } \\
\text { Kattığı }\end{array}$ & Bilgilendirici & Deneme & 2.919 & 7.645 & 61.602 & 35.544 & Orta-Eğitsel \\
\hline $\begin{array}{l}\text { Anneciğim } \\
\text { Anneciğim }\end{array}$ & Öykülendirici & Anı & 2.849 & 12.225 & 52.46 & 32.917 & Orta-Engelli \\
\hline $\begin{array}{l}\text { Atatürk } \\
\text { Hakkında }\end{array}$ & Öykülendirici & Anı & 2.779 & 14.209 & 50.094 & 32.81 & Orta-Engelli \\
\hline $\begin{array}{l}\text { Hatıralar ve } \\
\text { Belgeler }\end{array}$ & & & & & & & \\
\hline $\begin{array}{l}\text { Atatürk Kişiliği, } \\
\text { İlkeleri, } \\
\text { Düşünceleri }\end{array}$ & Bilgilendirici & Biyografi & 2.471 & 8.914 & 76.288 & 45.955 & Kolay-Eğitse \\
\hline $\begin{array}{l}\text { Akılcılık, Bilim, } \\
\text { Eğitim }\end{array}$ & Bilgilendirici & Deneme & 2.773 & 12.205 & 55.565 & 34.911 & Orta-Engelli \\
\hline $\begin{array}{l}\text { Türkiye'nin } \\
\text { Jeopolitik Önemi }\end{array}$ & Bilgilendirici & Makale & 2.777 & 16.535 & 44.104 & 30.603 & Zor-Engelli \\
\hline $\begin{array}{l}\text { Atatürk ve } \\
\text { Abdulhalim } \\
\text { Çelebi Efendi }\end{array}$ & Öyküleyici & Anı & 2.766 & 8.430 & 65.699 & 38.758 & Orta-Eğitsel \\
\hline $\begin{array}{l}\text { Güney ve Batı } \\
\text { Anadolu } \\
\text { Ormanları }\end{array}$ & Bilgilendirici & $\begin{array}{l}\text { Haber } \\
\text { Yazısı }\end{array}$ & 2.509 & 16.656 & 54.554 & 37.45 & Orta-Eğitsel \\
\hline
\end{tabular}


Tablo (2) (Devamı): Bisiklet Yayınları 8. Sınıf Türkçe Ders Kitabındaki Metinlerin Okunabilirlik Düzeyleri

\begin{tabular}{|c|c|c|c|c|c|c|c|}
\hline $\begin{array}{l}\text { Dünya } \\
\text { Yuvarlakmış }\end{array}$ & Bilgilendirici & Makale & 2.701 & 13.644 & 54.703 & 35.385 & Orta-Eğitsel \\
\hline $\begin{array}{l}\text { Yanan } \\
\text { Ormanlarda Elli } \\
\text { Gün }\end{array}$ & Öyküleyici & Hikâye & 2.361 & 5.403 & 89.871 & 52.222 & Kolay-Bağımsız \\
\hline Geldiği Gibi & Bilgilendirici & Sohbet & 2.612 & 12.363 & 61.621 & 38.941 & Orta-Eğitsel \\
\hline Ceviz & Öyküleyici & Hikâye & 2.487 & 12.344 & 66.693 & 42.208 & Orta-Eğitsel \\
\hline Çalıkuşu & Öyküleyici & Roman & 2.614 & 8.528 & 71.55 & 42.613 & Kolay-Ĕgitsel \\
\hline $\begin{array}{l}\text { Herkesin Değeri } \\
\text { Kendine Göre }\end{array}$ & Bilgilendirici & Deneme & 2.962 & 10.095 & 53.48 & 32.048 & Orta-Engelli \\
\hline Misafirliklerimiz & Bilgilendirici & Sohbet & 2.742 & 13.818 & 61.315 & 33.929 & Orta-Eğitsel \\
\hline $\begin{array}{l}\text { Tarihin Tanığı } \\
\text { Yazı }\end{array}$ & Bilgilendirici & Makale & 2.747 & 13.811 & 52.419 & 34.027 & Orta-Eğitsel \\
\hline Tatlı Dil & Bilgilendirici & Sohbet & 2.441 & 10.116 & 74.356 & 45.567 & Kolay-Eğitsel \\
\hline $\begin{array}{l}\text { Bayan Hardy } \\
\text { Televizyonda }\end{array}$ & $\begin{array}{l}\text { Öykülendirici } \\
\text { Bilgilendirici }\end{array}$ & $\begin{array}{l}\text { Hikâye } \\
\text { Fıkra }\end{array}$ & $\begin{array}{l}2.696 \\
2.802\end{array}$ & $\begin{array}{l}13.648 \\
11.434\end{array}$ & $\begin{array}{l}54.893 \\
56.413\end{array}$ & $\begin{array}{l}35.511 \\
34.906\end{array}$ & $\begin{array}{l}\text { Orta-Eğitsel } \\
\text { Orta-Eğitsel }\end{array}$ \\
\hline Ergenlik Çağı & & & & & & & \\
\hline $\begin{array}{l}\text { Sana Mail'im Var } \\
\text { Çocuktum } \\
\text { Ufacıktım Top }\end{array}$ & $\begin{array}{l}\text { Öyküleyici } \\
\text { Öyküleyici }\end{array}$ & $\begin{array}{l}\text { Hikâye } \\
\text { Anı }\end{array}$ & $\begin{array}{l}2.733 \\
2.527\end{array}$ & $\begin{array}{l}9.621 \\
14.65\end{array}$ & $\begin{array}{l}63.917 \\
69.392\end{array}$ & $\begin{array}{l}38.46 \\
38.929\end{array}$ & $\begin{array}{l}\text { Orta-Eğitsel } \\
\text { Orta-Eğitsel }\end{array}$ \\
\hline Oynadım Acıktım & & & & & & & \\
\hline $\begin{array}{l}\text { Güney Amerika } \\
\text { Gezi İzlenimleri }\end{array}$ & Bilgilendirici & Gezi Yazısı & 2.564 & 8.820 & 75.797 & 43.629 & Kolay-Eğitsel \\
\hline $\begin{array}{l}\text { Hayalinizdeki } \\
\text { Oda }\end{array}$ & Bilgilendirici & Sohbet & 2.772 & 10.725 & 59.468 & 36.374 & Orta-Eğitsel \\
\hline $\begin{array}{l}\text { Zaman Yönetimi- } \\
\text { Büyük Taşlar }\end{array}$ & Öyküleyici & Hikâye & 2.629 & 8.878 & 70.034 & 41.884 & Kolay-Eğitsel \\
\hline Bir Göl Bir Deniz & Bilgilendirici & Mektup & 2.853 & 11.842 & 53.299 & 33.185 & Orta-Eğitsel \\
\hline
\end{tabular}

Tablo(2) incelendiğinde on beş bilgilendirici metinden Ateşman Okunabilirlik Formülüne göre "Türkiye'nin Jeopolitik Konumu" adlı metnin zor, "Hayatın Hesaba Kattı̆̆ı", "Akılcılık, Bilim, Eğitim", "Güney ve Batı Anadolu Ormanları", "Dünya Yuvarlakmış", "Geldiği Gibi", "Herkesin Değeri Kendine Göre", "Misafirliklerimiz", "Tarihin Tanığı Yazı", "Televizyonda Ergenlik Çağı", "Hayalinizdeki Oda", "Bir Göl Bir Deniz" adlı metinlerin orta, "Atatürk'ün Kişiliği, İlkeleri, Düşünceleri", "Tatlı Dil", "Güney Amerika Gezi İzlenimleri" adlı metinlerin kolay; Çetinkaya-Uzun Okunabilirlik formülüne göre, "Akılcılık, Bilim, Eğitim", "Türkiye'nin Jeopolitik Önemi", "Herkesin Değeri Kendine Göre" adlı metinlerin engelli, "Hayatın Hesaba Kattığı", "Atatürk'ün Kişiliği, İlkeleri, Düşünceleri", "Güney ve Batı Anadolu Ormanları", "Dünya Yuvarlakmış", "Geldiği Gibi", "Misafirliklerimiz", "Tarihin Tanığı Yazı","Tatlı Dil", "Televizyonda Ergenlik Çağı", "Güney Amerika Gezi İzlenimleri", "Hayalinizdeki Oda", "Bir Göl Bir Deniz" adlı metinlerin de eğitsel olduğunu görmekteyiz. ìki formüle göre ortak iki metin kolay düzeyde çıkmazken "Hayatın Hesaba Kattığı", "Güney ve Batı Anadolu Ormanları", "Dünya Yuvarlakmış", "Geldiği Gibi", "Misafirliklerimiz", "Tarihin Tanığı Yazı", "Televizyonda Ergenli Çağı", "Hayalinizdeki Oda", "Bir Göl Bir Deniz" adlı metinlerin orta düzeyde, "Türkiye’nin Jeopolitik Önemi" adlı metnin zor düzeyde olduğunu görmekteyiz. 
Tablo(2)'ye göre on üç öyküleyici metinden Ateşman Okunabilirlik Formülüne göre "Anneciğim Anneciğim", "Atatürk Hakkında Hatıralar ve Belgeler", "Atatürk ve Abdülhalim Çelebi", "Ceviz", "Bayan Hardy", "Sana Mail'im Var", "Çocuktum Ufacıktım Top Oynadım Acıktım" adlı metinlerin orta, "Meraklı Pandora ve Konuşan Sandık", "Aşk Mektupları", "Kazılık Dağının Aslanı Boğaç Han", "Yanan Ormanlarda Elli Gün", "Çalıkuşu", "Zaman Yönetimi-Büyük Taşlar" adlı metinlerin kolay; Çetinkaya-Uzun Okunabilirlik Formülüne göre, "Anneciğim Anneciğim", "Atatürk Hakkında Hatıralar ve Belgeler" adlı metinlerin engelli, "Meraklı Pandora ve Konuşan Sandık", "Aşk Mektupları", "Kazııık Dağının Aslanı Boğaç Han", "Atatürk ve Abdülhalim Çelebi", "Ceviz", "Çalıkuşu", "Bayan Hardy", "Sana Mail'im Var", "Çocuktum Ufacıktım Top Oynadım Acıktım", "Zaman YönetimiBüyük Taşlar" adlı metinlerin eğitsel, "Yanan Ormanlarda Elli Gün" adlı metnin de bağımsız okuma düzeyinde olduğu görülmektedir. Her iki formüle göre zor metin bulunmazken "Yanan Ormanlarda Elli Gün " adlı metnin kolay, "Atatürk ve Abdülhalim Çelebi", "Ceviz", "Bayan Hardy", "Sana Mail'im Var", "Çocuktum Ufacıktım Top Oynadım Acıktım" adlı metinlerin orta düzeyde olduğunu görmekteyiz.

Tablo(3): MEB Yayınları 8. Sınıf Türkçe Ders Kitabında Yer Alan Bilgilendirici Metinlerin Ateşman Okunabilirlik Formülüne Göre Yüzdelik Dağılımı

\begin{tabular}{lllllll}
\hline & Çok kolay & Kolay & Orta & Zor & Çok zor & Toplam \\
\hline $\begin{array}{l}\text { MEB Yayınları 8. } \\
\text { Sınıf }\end{array}$ & - & - & 8 & 5 & 1 & 14 \\
8. Sınıf (\%) & 0 & 0 & 57.14 & 35.71 & 7.14 & 100 \\
\hline
\end{tabular}

Tablo(3)'e baktığımızda MEB Yayınları 8. Sınıf Türkçe Ders Kitabında yer alan on dört bilgilendirici metnin Ateşman Okunabilirlik Formülüne göre okunabilirlik düzeyindeki dağılım şu şekildedir. 14 metinde çok kolay ve kolay düzeyinde metin bulunmazken sekiz metnin orta, beş metnin zor, bir metnin de çok zor düzeyde olduğunu görmekteyiz. Tablo incelendiğinde en çok dağılımın orta düzeyde (\%57.14), en az dağılımın çok zor düzeyde (\%7.14) olduğunu görmekteyiz.

Tablo(4): MEB Yayınları 8. Sınıf Türkçe Ders Kitabında Yer Alan Bilgilendirici Metinlerin ÇetinkayaUzun Okunabilirlik Formülüne Göre Yüzdelik Dağılımı

\begin{tabular}{lllll}
\hline Toplam & Bağımsız & Eğitsel & Engelli & Toplam \\
\hline MEB Yayınları 8.Sınıf & - & 7 & 7 & 14 \\
8. Sınıf (\%) & 0 & 50 & 50 & 100 \\
\hline
\end{tabular}

Tablo(4)'e baktığımızda MEB Yayınları 8. Sınıf Türkçe Ders Kitabında yer alan on dört bilgilendirici metnin Çetinkaya- Uzun Okunabilirlik Formülüne göre okunabilirlik düzeyindeki dağılım şu şekildedir. 14 metinden hiç bağımsız okuma düzeyinde metin bulunmazken yedi metnin eğitsel 
okuma, yedi metnin de engelli okuma düzeyinde olduğunu görmekteyiz. Tablo incelendiğinde eğitsel ve engelli okuma düzeylerinde eşit dağılım (\%50) olduğunu görmekteyiz

Tablo(5): MEB Yayınları 8. Sınıf Türkçe Ders Kitabında Yer Alan Öyküleyici Metinlerin Ateşman Okunabilirlik Formülüne Göre Yüzdelik Dağılımı

\begin{tabular}{lllllll}
\hline & Çok kolay & Kolay & Orta & Zor & Çok zor & Toplam \\
\hline MEB Yayınları 8. Sınıf & - & 7 & 5 & 2 & - & 14 \\
8. Sınıf (\%) & 0 & 50 & 35.71 & 14.28 & 0 & 100 \\
\hline
\end{tabular}

Tablo(5)'e baktığımızda MEB Yayınları 8. Sınıf Türkçe Ders Kitabında yer alan on dört öyküleyici metnin Ateşman Okunabilirlik Formülüne göre okunabilirlik düzeyindeki dağılım şu şekildedir. 14 metinde hiç çok kolay ve çok zor düzeyinde metin bulunmazken yedi metnin kolay, beş metnin orta, iki metnin de zor düzeyde olduğunu görmekteyiz. Tablo incelendiğinde en çok dağılımın kolay düzeyde (\%50), en az dağııııın zor düzeyde (\%14.28) olduğunu görmekteyiz.

Tablo(6): MEB Yayınları 8. Sınıf Türkçe Ders Kitabında Yer Alan Öyküleyici Metinlerin Çetinkaya-Uzun Okunabilirlik Formülüne Göre Yüzdelik Dağılımı

\begin{tabular}{lllll}
\hline Toplam & Bağımsız & Eğitsel & Engelli & Toplam \\
\hline MEB Yayınları 8.Sınıf & 1 & 10 & 3 & 14 \\
8. Sınıf (\%) & 7.14 & 71.42 & 21.42 & 100 \\
\hline
\end{tabular}

Tablo(6)'ya baktığımızda MEB Yayınları 8. Sınıf Türkçe Ders Kitabında yer alan on dört öyküleyici metnin Çetinkaya- Uzun Okunabilirlik Formülüne göre okunabilirlik düzeyindeki dağılım şu şekildedir. 14 metinden bir metnin bağımsız okuma on metnin eğitsel okuma, üç metnin de engelli okuma düzeyinde olduğunu görmekteyiz. Tablo incelendiğinde en çok dağııımın eğitsel okuma düzeyinde (\%71.42), en az dağıımın bağımsız okuma düzeyinde (\%7.14) olduğunu görmekteyiz.

Tablo(7): Bisiklet Yayınları 8. Sınıf Türkçe Ders Kitabında Yer Alan Bilgilendirici Metinlerin Ateşman Okunabilirlik Formülüne Göre Yüzdelik Dağılımı

\begin{tabular}{lllllll}
\hline & Çok kolay & Kolay & Orta & Zor & Çok zor & Toplam \\
\hline Bisiklet Yayınları 8. Sınıf & - & 3 & 11 & 1 & - & 15 \\
8. Sınıf (\%) & 0 & 20 & 73.33 & 6.66 & 0 & 100 \\
\hline
\end{tabular}

Tablo(7)'ye baktığımızda Bisiklet Yayınları 8. Sınıf Türkçe Ders kitabında yer alan on beş bilgilendirici metnin Ateşman Okunabilirlik Formülüne göre okunabilirlik düzeyinin dağılımı şu şekildedir. 15 metinden çok kolay ve çok zor düzeyinde hiç metin bulunmazken bir metnin kolay, on 
bir metnin orta, üç metnin zor düzeyde olduğunu görmekteyiz. Tablo incelendiğinde en çok dağılım orta düzeyde (\%73.33), en az dağılım zor düzeyinde (\%6.66) olduğu görülmektedir.

Tablo(8): Bisiklet Yayınları 8. Sınıf Türkçe Ders Kitabında Yer Alan Bilgilendirici Metinlerin ÇetinkayaUzun Okunabilirlik Formülüne Göre Yüzdelik Dağılımı

\begin{tabular}{lllll}
\hline Toplam & Bağımsız & Eğitsel & Engelli & Toplam \\
\hline Bisiklet Yayınları 8.Sınıf & - & 12 & 3 & 15 \\
8. Sınıf (\%) & 0 & 80 & 20 & 100 \\
\hline
\end{tabular}

Tablo(8)'e baktığımızda Bisiklet Yayınları 8. Sınıf Türkçe Ders kitabında yer alan on beş bilgilendirici metnin Çetinkaya-Uzun okunabilirlik Formülüne göre okunabilirlik düzeyindeki dağılımı şu şekildedir. 15 metinden bağımsız okuma düzeyinde metin bulunmazken on iki metnin eğitsel okuma, üç metnin engelli okuma düzeyinde olduğunu görmekteyiz. Tablo incelendiğinde en çok dağılım eğitsel okuma düzeyindeyken (\%80) en az dağııım engelli okuma düzeyinde (\%20) olduğunu görmekteyiz.

Tablo(9): Bisiklet Yayınları 8. Sınıf Türkçe Ders Kitabında Yer Alan Öyküleyici Metinlerin Ateşman Okunabilirlik Formülüne Göre Yüzdelik Dağılımı

\begin{tabular}{lllllll}
\hline & Çok kolay & Kolay & Orta & Zor & Çok zor & Toplam \\
\hline Bisiklet Yayınları 8. Sınıf & - & 5 & 8 & - & - & 13 \\
8. Sınıf (\%) & 0 & 38.46 & 61.53 & 0 & 0 & 100 \\
\hline
\end{tabular}

Tablo(9)'a incelediğimizde Bisiklet Yayınları 8. Sınıf Türkçe Ders Kitabında yer alan on üç öyküleyici metnin Ateşman Okunabilirlik formülüne göre okunabilirlik düzeyindeki dağılımı şu şekildedir: 13 metinden çok kolay, zor ve çok zor düzeylerinde metin bulunmazken beş metnin kolay, sekiz metnin orta düzeyde olduğunu görmekteyiz. Tablo incelendiğinde en çok dağılım orta düzeyde (61.53), en az dağııım kolay düzeyde (38.46) olduğunu görmekteyiz.

Tablo(10): Bisiklet Yayınları 8. Sınıf Türkçe Ders Kitabında Yer Alan Öyküleyici Metinlerin ÇetinkayaUzun Okunabilirlik Formülüne Göre Yüzdelik Dağıımı

\begin{tabular}{lllll}
\hline Toplam & Bağımsız & Eğitsel & Engelli & Toplam \\
\hline Bisiklet & Yayınları & 10 & & \\
8.Sınıf & 1 & 10 & 2 & 13 \\
8. Sınıf (\%) & 7.69 & 76.92 & 15.38 & 100 \\
\hline
\end{tabular}

Tablo(10)’a baktığımızda Bisiklet Yayınları 8. Sınıf Türkçe Ders kitabında yer alan on üç öyküleyici metnin Çetinkaya-Uzun Okunabilirlik Formülüne göre okunabilirlik düzeyindeki dağılım şu 
şekildedir. 13 metinden bir metnin bağımsız, on metnin eğitsel, iki metnin engelli okuma düzeyinde olduğunu görmekteyiz. Tablo incelendiğinde en çok dağıım eğitsel okuma düzeyinde(76.92) en az dağılım bağımsız okuma düzeyinde (7.69) olduğunu görmekteyiz.

Tablo(11): MEB ve Bisiklet Yayınları 8. Sınıf Türkçe Ders Kitabında Yer Alan Metinlerin Ateşman Okunabilirlik Formülüne Göre Yüzdelik Dağılımı

\begin{tabular}{lllllll}
\hline & Çok kolay & Kolay & Orta & Zor & Çok zor & Toplam \\
\hline 8. Sınıf (2 Kitap) & - & 16 & 31 & 8 & 1 & 56 \\
8. Sınıf (\%) & 0 & 28.57 & 55.35 & 14.28 & 1.78 & 100 \\
\hline
\end{tabular}

Tablo(11)'e baktığımızda Bisiklet ve MEB yayınları 8. Sınıf Türkçe Ders kitabında yer alan 56 metnin Ateşman Okunabilirlik formülüne göre dağıımı şu şekildedir. 56 metinden çok kolay düzeyinde metin bulunmazken on altı metnin kolay, otuz bir metnin orta, sekiz metnin zor, bir metnin de çok zor düzeyde olduğunu görmekteyiz. Tablo incelendiğinde en çok dağılım orta düzeyde(\%55.35), en az dağılım de çok zor düzeyde (\%1.78) olduğunu görmekteyiz.

Tablo(12): MEB ve Bisiklet Yayınları 8. Sınıf Türkçe Ders Kitabında Yer Alan Metinlerin Çetinkaya-Uzun Okunabilirlik Formülüne Göre Yüzdelik Dağılımı

\begin{tabular}{lllll}
\hline Toplam & Bağımsız & Eğitsel & Engelli & Toplam \\
\hline 8.Sınıf (2 Kitap) & 2 & 39 & 15 & 56 \\
8. Sınıf (\%) & 3.57 & 69.64 & 26.78 & 100 \\
\hline
\end{tabular}

Tablo(12)'ye baktığımızda MEB ve Bisiklet Yayınları 8. Sınıf Türkçe ders kitabında yer alan 56 metnin Çetinkaya-Uzun Okunabilirlik Formülüne göre okunabilirlik düzeyi dağılımları şu şekildedir. 56 metinden iki metnin bağımsız okuma, otuz dokuz metnin eğitsel okuma, on beş metnin de engelli okuma düzeyinde olduğunu görmekteyiz. Tablo incelendiğinde en çok dağılım eğitsel okuma düzeyinde(\%69.64), en az dağılım de bağımsız okuma düzeyinde (3.57) olduğunu görmekteyiz

\section{Sınıf Türkçe Ders Kitaplarındaki Bilgilendirici Metinlerin Okunabilirlik Düzeyi Ile Ilgili Bulgular}

Tablo(13): MEB Yayınları 8. Sınıf Türkçe Ders Kitabındaki Bilgilendirici Metinlerin Ateşman Okunabilirlik Formülüne Göre Okunabilirlik Düzeyleri

\begin{tabular}{lll}
\hline Türü & Sayısı & Düzeyi \\
\hline Sohbet & 2 & Orta-Orta \\
Gezi Yazısı & 2 & Orta-Orta \\
Deneme & 2 & Orta-Zor \\
Haber Yazısı & 2 & Çok Zor-Zor \\
Makale & 1 & Zor \\
\hline
\end{tabular}


Tablo(13) (Devamı) MEB Yayınları 8. Sınıf Türkçe Ders Kitabındaki Bilgilendirici Metinlerin Ateşman Okunabilirlik Formülüne Göre Okunabilirlik Düzeyleri

\begin{tabular}{lll}
\hline Biyografi & 1 & Zor \\
Konferans & 1 & Zor \\
Mektup & 1 & Orta \\
Nutuk & 1 & Zor \\
Fikra & 1 & Zor \\
\hline
\end{tabular}

Tablo(13)'ü incelediğimizde MEB Yayınlarında on farklı bilgilendirici metin türünün kullanılmış ve toplamda on dört bilgilendirici metin bulunmaktadır. Bu bilgilendirici metinlerden Ateşman Okunabilirlik Formülüne göre altı metnin orta, yedi metnin zor, bir metnin çok zor düzeyde olduğunu görmekteyiz. Yani ders kitabında yer alan bilgilendirici metinlerin çoğunluğunun zor düzeyde olduğunu söyleyebiliriz.

Tablo(14): MEB Yayınları 8. Sınıf Türkçe Ders Kitabındaki Bilgilendirici Metinlerin Çetinkaya-Uzun Okunabilirlik Formülüne Göre Okunabilirlik Düzeyleri

\begin{tabular}{lll}
\hline Türü & Sayısı & Düzeyi \\
\hline Sohbet & 2 & Eğitsel-Eğitsel \\
Gezi Yazısı & 2 & Eğitsel-Eğitsel \\
Deneme & 2 & Eğitsel-Engelli \\
Haber Yazısı & 2 & Engelli-Engelli \\
Makale & 1 & Engelli \\
Biyografi & 1 & Engelli \\
Konferans & 1 & Eğitsel \\
Mektup & 1 & Eğitsel \\
Nutuk & 1 & Engelli \\
Fıkra & 1 & Engelli \\
\hline
\end{tabular}

Tablo(14)'ü incelendiğinde MEB Yayınları ders kitabında yer alan bilgilendirici metinlerin Çetinkaya-Uzun Okunabilirlik Formülüne göre yedi metnin engelli düzeyde, yedi metnin eğitsel düzeyde olduğunu yeni metinlerin düzeylerinin yarı yarıya olduğunu görebiliyoruz.

Tablo(15): Bisiklet Yayınları 8. Sınıf Türkçe Ders Kitabındaki Bilgilendirici Metinlerin Ateşman Okunabilirlik Formülüne Göre Okunabilirlik Düzeyleri

\begin{tabular}{lll}
\hline Türü & Sayısı & Düzeyi \\
\hline Sohbet & 4 & Orta-Orta-Orta-Kolay \\
Gezi Yazısı & 2 & Kolay-Orta \\
Deneme & 3 & Orta-Orta-Orta \\
Haber Yazısı & 1 & Orta \\
Makale & 3 & Zor-Orta-Orta \\
Biyografi & 1 & Kolay \\
Fıkra & 1 & Orta \\
\hline
\end{tabular}


Tablo(15)'i incelediğimizde Bisiklet Yayınları'nda yedi bilgilendirici metin türünün kullanıldığı ve toplamda on beş bilgilendirici metin bulunmaktadır. Bu metinlerden Ateşman Okunabilirlik Formülüne göre üç metnin kolay, on bir metnin orta, bir metnin de zor düzeyde olduğunu görmekteyiz. Ders kitabında yer alan bilgilendirici metinlerin çoğunluğunun orta düzeyde olduğunu söyleyebiliriz.

Tablo(16): Bisiklet Yayınları 8. Sınıf Türkçe Ders Kitabındaki Bilgilendirici Metinlerin Çetinkaya-Uzun Okunabilirlik Formülüne Göre Okunabilirlik Düzeyleri

\begin{tabular}{lll}
\hline Türü & Sayısı & Düzeyi \\
\hline Sohbet & 4 & Eğitsel-Eğitsel-Eğitsel-Ĕgitsel \\
Gezi Yazısı & 2 & Eğitsel-Eğitsel \\
Deneme & 3 & Eğitsel-Engelli-Engelli \\
Haber Yazısı & 1 & Eğitsel \\
Makale & 3 & Eğitsel-Engelli-Engelli \\
Biyografi & 1 & Eğitsel \\
Fıkra & 1 & Eğitsel \\
\hline
\end{tabular}

Tablo(16)'yı incelediğimizde Bisiklet Yayınları ders kitabında yer alan bilgilendirici metinlerden Çetinkaya-Uzun Okunabilirlik Formülüne göre on bir tanesinin eğitsel düzey, dört tanesinin engelli düzeyde olduğunu görmekteyiz. Yani bilgilendirici metinlerin büyük çoğunluğunun eğitsel düzeyde olduğunu söyleyebiliriz.

\section{Sınıf Türkçe Ders Kitaplarındaki Öyküleyici Metinlerin Okunabilirlik Düzeyi Ile Illgili Bulgular}

Tablo(17): MEB Yayınları 8. Sınıf Türkçe Ders Kitaplarındaki Öyküleyici Metinlerin Ateşman Okunabilirlik Formülüne Göre Okunabilirlik Düzeyleri

\begin{tabular}{lll}
\hline Türü & Sayısı & Düzeyi \\
\hline Hikâye & 6 & Kolay-Kolay-Kolay-Kolay-Orta-Zor \\
Roman & 2 & Kolay-Zor \\
Anı & 3 & Kolay-Orta-Orta \\
Destan & 1 & Kolay \\
Efsane & 1 & Orta \\
\hline
\end{tabular}

Tablo(17)'yi incelediğimizde MEB Yayınlarında beş faklı öyküleyici metin türü yer almaktadır. Toplamda on üç öyküleyici metin vardır. Bu öyküleyici metinlerden Ateşman Okunabilirlik Formülüne göre yedi metnin kolay, dört metnin orta, iki metnin zor düzeyde oluğunu görmekteyiz. Yani öyküleyici metinlerinin çoğunluğunun orta düzeyde olduğunu söyleyebiliriz. 
Tablo(18): MEB Yayınları 8. Sınıf Türkçe Ders Kitaplarındaki Öyküleyici Metinlerin Çetinkaya-Uzun Okunabilirlik Formülüne Göre Okunabilirlik Düzeyleri

\begin{tabular}{lll}
\hline Türü & Sayısı & Düzeyi \\
\hline Hikâye & 6 & Eğitsel-Eğitsel-Eğitsel-Eğitsel- \\
& & Eğitsel-Engelli \\
Roman & 2 & Bağımsız Okuma-Engelli \\
Anı & 3 & Eğitsel-Eğitsel-Engelli \\
Destan & 1 & Eğitsel \\
Efsane & 1 & Eğitsel \\
\hline
\end{tabular}

Tablo(18)'i incelediğimizde MEB Yayınları 8. Sınıf Türkçe Ders Kitabında Bulunan on üç öyküleyici metinden Çetinkaya-Uzun Okunabilirlik Formülüne göre bir metnin bağımsız okuma, dokuz metnin eğitsel okuma, üç metnin de engelli okuma düzeyinde olduğunu görmekteyiz. Yani öyküleyici metinlerin çoğunluğunun eğitsel okuma düzeyinde olduğunu söyleyebiliriz.

Tablo(19): Bisiklet Yayınları 8. Sınıf Türkçe Ders Kitaplarındaki Öyküleyici Metinlerin Ateşman Okunabilirlik Formülüne Göre Okunabilirlik Düzeyleri

\begin{tabular}{lll}
\hline Türü & Sayısı & Düzeyi \\
\hline Hikâye & 6 & Kolay-Kolay-Kolay-Orta-Orta-Orta \\
Roman & 1 & Kolay \\
Anı & 4 & Orta-Orta-Orta-Orta \\
Destan & 1 & Kolay \\
Efsane & 1 & Kolay \\
\hline
\end{tabular}

Tablo(19)'u incelediğimizde Bisiklet Yayınları 8. Sınıf Türkçe Ders Kitabında 5 farklı öyküleyici metin türü bulunmaktadır. Toplamda on üç öyküleyici metin türü vardır. Bu metinlerden Ateşman Okunabilirlik Formülüne göre altı metnin kolay, yedi metnin orta düzeyde olduğunu görmekteyiz. Yani metinlerin çoğunluğunun orta düzeyde olduğunu söyleyebiliriz.

Tablo(20): Bisiklet Yayınları 8. Sınıf Türkçe Ders Kitaplarındaki Öyküleyici Metinlerin Çetinkaya-Uzun Okunabilirlik Formülüne Göre Okunabilirlik Düzeyleri

\begin{tabular}{lll}
\hline Türü & Sayısı & Düzeyi \\
\hline Hikâye & 6 & Bağımsı-Eğitsel-Eğitsel-Eğitsel- \\
& & Eğitsel-Eğitsel \\
Roman & 1 & Eğitsel \\
Anı & 4 & Engelli-Engelli-Eğitsel-Eğitsel \\
Destan & 1 & Eğitsel \\
Efsane & 1 & Eğitsel \\
\hline
\end{tabular}

Tablo(20)'yi incelendiğinde Bisiklet Yayınları 8. Sınıf Türkçe Ders Kitabında yer alan on üç öyküleyici metinden Çetinkaya-Uzun Okunabilirlik Formülüne göre bir metnin bağımsız okuma, on 
metnin eğitsel okuma, üç metnin de engelli okuma düzeyinde olduğunu görmekteyiz. Yani metinlerin çoğunluğunun eğitsel okuma düzeyinde olduğunu görmekteyiz.

\section{Sonuç ve Tartışma}

Ders kitaplarında yer alan metinlerin okunabilirliklerinin öğrenci seviyesine uygunluğunu belirlemek amacıyla yapılan bu çalışmaya göre MEB ve Bisiklet Yayınları 8. sınıf Türkçe ders kitaplarında yer alan bilgilendirici ve öyküleyici 56 metnin çoğunluğunun okunabilirlik düzeyinin orta düzeyde olduğu görülmektedir. Ateşman okunabilirlik formülüne göre 56 metnin $\% 55.35$ 'i orta düzeyde, Çetinkaya-Uzun okunabilirlik formülüne ise göre \%69.64'ü eğitsel okuma düzeyindedir. Yani ders kitaplarında yer alan metinlerin çoğunluğunun 8. sınıf öğrencisinin okuma seviyesine uygun olduğu ortaya çıkmaktadır.

Çalışmada ele alınan bilgilendirici ve öyküleyici metinlerden bilgilendirici metinlerin öyküleyici metinlere göre okunabilirliğinin daha zor düzeyde olduğu belirlenmiştir. Öyküleyici metin türlerinden Ateşman okunabilirlik formülüne göre çok zor düzeyinde metin bulunmazken, bilgilendirici metin türünde ise bu düzeyde metinlere rastlanmıştır. Ayrıca Çetinkaya-Uzun formülüne göre bilgilendirici metin türünde bağımsız okuma düzeyinde metinlere rastlanmazken, öyküleyici metin türünde bu düzeyde metne rastlanmıştır.

Okur ve Arı (2013) tarafından yapılan araştırmanın sonuçlarına göre 8.sınıf Türkçe ders kitaplarında yer alan metinlerin Ateşman Okunabilirlik Formülüne göre en çok dağıımın orta düzeyde(\%46.02), Çetinkaya-Uzun Okunabilirlik Formülüne göre ise en çok dağılımın eğitsel okuma düzeyinde (\%64.60) olduğu belirlenmiştir.

Aynı çalışmada Ateşman formülüne göre bilgilendirici ve öyküleyici metinlerin okunabilirlik düzeyi karşılaştırıldı̆̆ında, bilgilendirici metinlerin okunabilirlik düzeyinin öyküleyici metinlere göre daha zor olduğu da belirlenmiştir. Çetinkaya-Uzun formülüne göre ise öyküleyici metinlerin okunabilirliği bilgilendirici metinlere göre daha kolaydır.

Okur ve Arı́nın yapmış olduğu çalışmanın sonuçlarıyla yapılan bu çalışmanın sonuçları karşılaştırıldığında her iki çalışmada ortaya çıkan sonuç 8. sınıf Türkçe ders kitaplarında yer alan metinlerin çoğunluğunun Ateşman formülüne göre orta düzeyde, Çetinkaya-Uzun formülüne göre ise eğitsel okuma düzeyinde olduğudur. Ayrıca her iki çalışma sonucuna göre ders kitaplarında yer alan bilgilendirici metinlerin okunabilirlik seviyeleri öyküleyici metinlerin okunabilirlik seviyelerine göre daha zordur.

Arı ve Okur'un (2013)'de yapmış olduğu çalışmanın sonuçlarıyla paralellik gösteren bu çalışma Ateşman'ın (1997)'de yapmış olduğu bir başka çalışmanın sonuçlarıyla da örtüşmektedir. Ateşman'ın çalışmasında bilgilendirici metinlerin hece ve kelime uzunluklarının öyküleyici metinlerin hece ve 
kelime uzunluklarına göre daha uzun olduğu ve belirlenen bu sonuca göre Ateşman'ın çalışmasında da bilgilendirici metinlerin öyküleyici metinlere göre daha zor düzeyde olduğu tespit edilmiştir.

Yukarıda ifade edilen her iki çalışmanın sonuçlarıyla paralellik gösteren bu çalışmada 8. sınıf Türkçe ders kitaplarında yer alan bilgilendirici metinlerin okunabilirlik düzeyleri öyküleyici metinlerin okunabilirlik düzeylerine göre daha zor olduğu sonucuna ulaşılmıştır.

\section{Kaynakça}

Ateşman, E. (1997). Türkçede okunabilirliğin ölçülmesi. A.Ü. TÖMER Dil Dergisi. 58, 171-174

Altan, A. , Arhan, S. , Başar, S. , Öztürker, G., Yılmaz, D. (2012). ve Özbay M. (Ed.). İlköğretim 8. sınıf Türkçe ders kitabı. (5. Baskı). Ankara: Milli Eğitim Bakanlığı Yayınları.

Bağcı, H. (2008). Mehmet Akif Ersoy'un manzum hikâyelerinin okunabilirliği. 1. Uluslar arası Mehmet Akif Ersoy Sempozyumu Sempozyum Kitabı (ss). Burdur: Mehmet Akif Ersoy Üniversitesi Eğitim Fakültesi

Çetinkaya, G. (2010). Türkçe metinlerin okunabilirlik düzeylerinin tanımlanması ve sınıflandırılması. Yayınlanmamış Doktora Tezi. Ankara: Ankara Üniversitesi Sosyal Bilimler Enstitüsü.

Çiftçi,Ö. , Çeçen, M.A. , Melenlioğlu, D. (2009). Altıncı sınıf ders kitaplarındaki metinlerin okunabilirlik açısından değerlendirilmesi. Elektronik Sosyal Bilimler Dergisi, 6, 206- 219.

Göğüş, B. (1978). Orta dereceli okullarımızda Türkçe ve yazın eğitimi. Ankara: Kadıoğlu Matbaası.

Güneş, F. (2000). Çocuk kitaplarının okunabilirlik ölçüleri açısından incelenmesi. 1. Ulusal Çocuk Kitapları Sempozyumu. A.Ü. TÖMER Dil Öğretim Merkezi.

Okur, A. , Arı, G. (2013). 6,7,8. Sınıf Türkçe ders kitaplarındaki metinlerin okunabilirliği. ilköğretim Online, 12(1), 202- 226.

Özbay, M. (2002). Öğretmen görüşlerine göre Ankara merkez ilköğretim okullarında Türkçe öğretimi. Ankara.

Sever, S. (2003). Çocuk ve edebiyat. Ankara: Kök Yayıncılık. s.17

Solmaz, E. , Güyer, T. , Temur, T. (2009). Bilgisayar destekli metin okunabilirliği analizi. Türk Eğitim Bilimleri Dergisi, Bahar, 7 (4), 751- 766.

Şahin, D. (2012). ve Kara, M. (Ed.). İlköğretim 8. sınıf Türkçe ders kitabı. Ankara: Bisiklet Yayıncılık.

Temur, T. (2004). Okunabilirlik (Readability) kavramı. Türklük Bilimi Araştırmaları. Bahar,13, 169-180.

Zorbaz, K. Z. (2007). Türkçe ders kitaplarındaki masalların kelime- cümle uzunlukları ve okunabilirlik düzeyleri üzerine bir değerlendirme. Eğitimde Kuram ve Uygulama, 3(1), 87-101. 